\title{
外乱オブザーバによる電動サーボ系の非線形摩擦補償
}

\author{
正員岩崎誠 (名古屋工大) \\ 学生員 鬼頭 芳 明 (名古屋工大) \\ 正員 松井 信 行 (名古屋工大)
}

\section{Disturbance Observer-Based Nonlinear Friction Compensation in Servo Drive System}

Makoto Iwasaki, Member, Yoshiaki Kitoh, Student Member, Nobuyuki Matsui, Member

(Nagoya Institute of Technology)

Solid friction in various machines is one of dominant nonlinearities limiting the control performance of servo drive systems. Nonlinear friction gives tracking errors and undesired stick-slip motion due to stiction (breakaway friction) and/or Stribeck effect. A wide variety of studies have been reported, which formulated nonlinear friction models, identified its parameters, and compensated for the friction. Those compensation schemes can significantly improve the conventional control performance, however, deterioration of the control accuracy is still the problems due to the inaccurate friction model and/or the restricted bandwidth of the compensation control loop.

This paper presents the disturbance observer-based compensation for nonlinear friction in servo drive systems to improve the control performance. The proposed scheme uses a new disturbance observer which is designed on the basis of Coulomb friction characteristics. This scheme can realize the precise speed/position control without response delay which is caused by the restricted bandwidth in the conventional compensation scheme. Experimental results and analytical studies show the distinct performance improvement of the proposed scheme, comparing to the conventional compensation schemes.

キーワード : 非線形摩擦，摩摖補償，クーロン摩擦モデル，外乱才ブザーバ，フィードフォワード制御

\section{1. まえがき}

電力変換器やマイクロプロセッサの高性能化・高機能化 によって電動サーボ技術は急速に発展し,電動機はより複 雑な負荷機械系の駆動源として用いられるようになってき た。その場合，機械系には種々の非線形要素が含まれること が多く、サーボ系の制御精度に影響を与えることが知られ ている。固体摩擦に代表される非線形摩擦は非線形要素の 一つに挙げられ，それはX-Y テーブル駆動の象限切換え時 のトラッキングエラーや，低加速度運転時や微小送り制御時 のスティック・スリップモーション等の原因となり, 制御精 度低下を招く(1)。また，サ一ボ采の機械パラメー夕同定を 行う場合, 非線形摩擦は同定精度に悪影響を与えることも 報告されている(2)。

これらの非線形摩擦に起因する問題点の補償は古くから の研究テーマであり,摩摖の精密モデリング技術の発展(3)(4) と共に，数多くの補償アルゴリズムが提案されてきた。そ れらの代表的な手法は，大きく 2 つに分類できる。1つは， 摩擦の精密モデルに基づいたフィードフォワード形補償で あり，他方は，精密な摩擦の情報を特に必要としないフィー ドバック形補償法である。フィードフォワード形の代表と
しては，速度力向反転時や始動時に摩擦トルクを強制印加 するバンバン制御(5)が挙げられ, 状態オブザーバやカルマ ンフィルタ ${ }^{(6)}$ 等による摩擦モデリング技術の発展を背景と した実用性の高い手法である。フィードバック形としては， 瞬時摩擦をオブザーバにより推定して補償する方法(7)(8)や， 繰り返し学習によって摩擦の影響を除去する方法 ${ }^{(9)}$ が挙げ られ, システム外乱やパラメータ変動に対するロバスト性な どを併せて論ずる事のできる特街を有している。各手法は それぞれの適用対象に応じた優れた特性を有するが,バン バン制御は純粋なフィードフォワード補償であるため摩擦 モデルの誤差が，また，オブザーバ併用形制御ではオブザー バ応答帯域の制限による摩摖推定誤差が，それぞれ制御精 度低下を招くことが指摘されている(10)。

このような背景の中で, 本研究は電動サーボ系に於ける 速度方向反転時及び位置送り制御時の速度 - 位置制御特性 改善を目的に，制御モデルにクーロン摩摖特性を考虑した 新しい外乱オブザーバを用いた摩擦補償法を提案するもの である(11)(12)。筆者等は先に, バンバン制御之外乱オブザー バを併用した速度サーボ系の非線形摩擦補償法に関する考 察・検証を行なってきた(10)。その方法に依れば，予め設定 
DD BLDC Motor Mechanical Brake

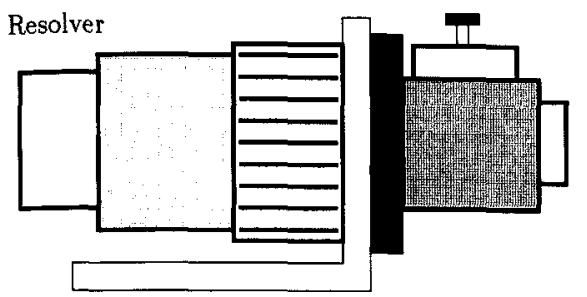

図 1 供試システム構成

Fig. 1. System configuration of prototype.

表 1 供試システム諸元

Table 1. Specifications of prototype.

\begin{tabular}{l|l}
\hline 機珹パラメータ \\
\hline$J_{M}: 1.9 \times 10^{-3}\left[\mathrm{kgm}^{2}\right]$ & $\begin{array}{l}\text { 定格速度 : } 43[\mathrm{rpm}] \\
\text { 定格電流 : } 0.85[\mathrm{~A}]\end{array}$ \\
\hline 定格トルク $: 3.9[\mathrm{Nm}]$ \\
\hline $\begin{array}{c}\text { 制御周期 } \\
\text { トルク制御 : } 200[\mu \mathrm{s}]\end{array}$ & 速度制御 : $200[\mu \mathrm{s}]$ \\
位置制御 : $: 2[\mathrm{~ms}]$ & \\
\hline
\end{tabular}

したバンバントルクに誤差が含まれていても, 外乱オブザー バが元来有する高速外乱抑圧機能により, 摩擦モデル誤差 による制御精度劣化を補償可能であり，従来のバンバン制 御法の欠点を克服できる。しかし，摩擦特性は摩摖摺動面 の潤滑状態等によって変化する場合が多く, 如何なる状態 に対しても一定のバンバントルクを与えることは, 制御精 度のばらつきの点からも不利であり,さらにバンバントル クの初期同定または現場調整が不可欠である。それに対し， 本論文で提案する外乱オブザーバは, クーロン摩擦の速度符 号関数を内在したシステム外乱モデに基づいて構成され る結果, 速度反転直前の摩擦值を反転後の外乱オブザーバ 初期値として自動設定する機能を有している。従って, 本摩 擦補償法は，バンバン補償トルクの自動発生機能を持つ外 乱オブザーバ併用形補償法と位置付けることができる。文 献 (7)(13) 等には, クーロン摩擦を考慮した状態オブザーバ 併用形状態フィードバック制御系によるサーボ系の摩擦補 償法が提案されているが, 本研究で提案する手法は, 速度符 号関数を内在する極めて簡単な構成の外乱オブザーバのみ によるフィードフォワード補償法である。提案の外乱オブ ザーバ併用形補償法に依れば, 従来の各種補償法に比して 速度方向反転時及び始動時の摩摖推定遅れが大幅に改善で き, 速度 、位圈制御精度の向上が達成可能である。本法は, 供試システムを用いた実験及び非線形摩擦モデルを用いた 特性解析によってその有効性が示されている。

\section{2. 、非線形摩擦のサーボ系への影響(10)}

本章では，非線形摩擦が従来のサ一ボ系制御精度へ与え る影響の考察として，X-Y テーブル駆動の象限切換え等で 経験される, 速度方向反転時の速度応答遅れに起因する制

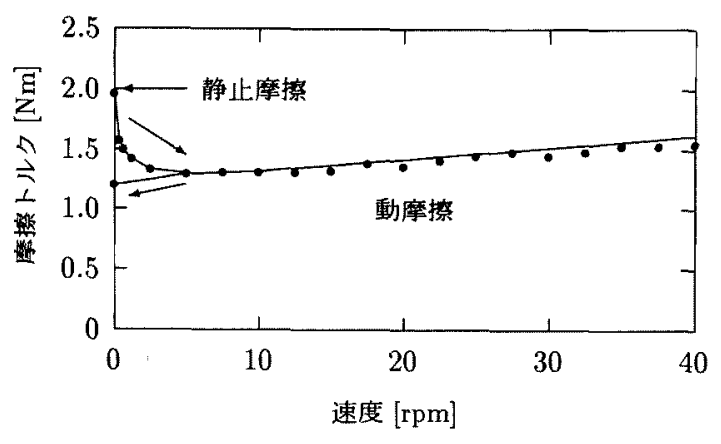

(a) 摩擦静特性

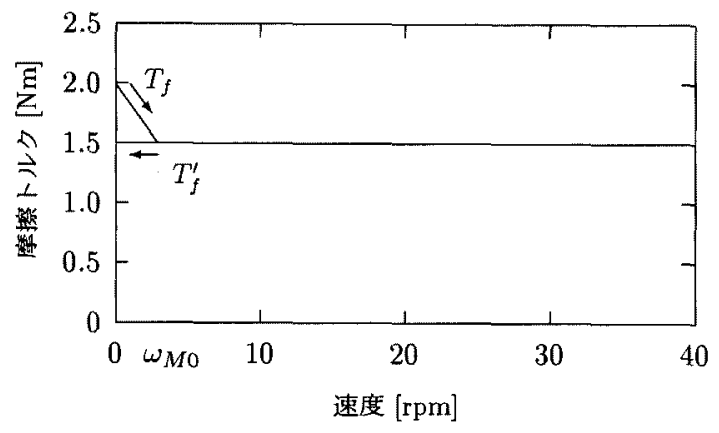

(b) 特性解析用摩擦モデル

図 2 システム摩擦特性と解析用モデル

Fig. 2. Measured system friction characteristic and model.

御精度低下を実験的に検証する。

<2.1> 供試システム構成 本研究で用いた供試シス テムは, 図 1 に示すようにダイレクトドライブモータ (DD BLDC モータ)に負荷として機械的ブレーキを取り付けた ものである。システム諸元を表 1 に, システム全体の摩擦静 特性を図 2(a)にそれぞれ示す。図 2(a) から,静止摩擦から 動摩擦に変化する際に, 速度に対して負勾配を持つ特性を 示すことがわかる。本論文では, 摩摖特性の非線形性を, 電 動機速度上昇時上下降時で速度に対する摩擦勾配が変化す る事と定義するが, 速度变化状態によってはその勾配が変動 することがある。また，図 2(b) は後述の制御特性解析に用 いる摩擦モデルである。摩摖モデルでは, 電動機速度上昇時 にはシステムの静特性に倣って負勾配を仮定し, 速度下降時 は静止摩擦へ遷移しないクーロン摩擦ししている。ここで, 摩擦モデルの各摩擦值は回転方向に依らず同一としている。

電動機トルク，速度，位置の各制御処理は, DSP (TMS $32010,20 \mathrm{MHz}$ ) を用いた全ソフトウェア制御系によって行 なわれている。また, 電動機速度検出に用いたレゾルバ(速 度検出分解能 $0.04 \mathrm{rpm}$ ) は, 速度方向の符号判定に対して 十分な精度を持っていると考えられる。

<2.2> 従来の摩摖補償法による速度反転特性図 3 は, 速度制御として比例積分補償 (以下 PI 補償) を用いた 場合の速度反転特性である。ここで, PI 補償ゲイン $\left(K_{S P}\right.$; 比例ゲイン, $K_{S I}$; 積分ゲイン) は, 速度制御系の特性方程 式が減衰係数 $\zeta=1.0$, 固有角周波数 $\omega_{n}=200 \mathrm{rad} / \mathrm{s}$ を満た 


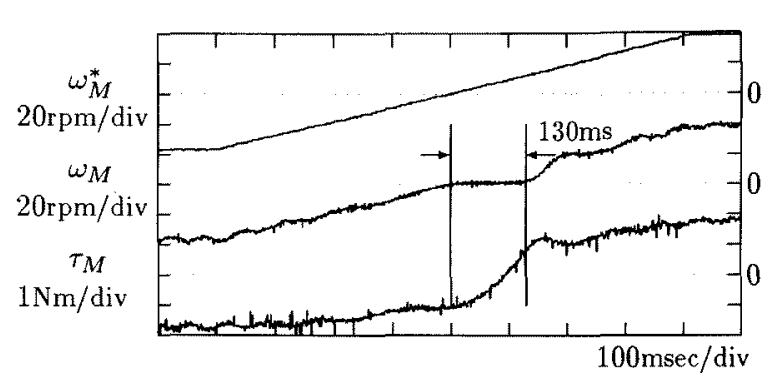

図 3 PI 補償による速度反転特性

Fig. 3. Velocity profile using PI regulator.

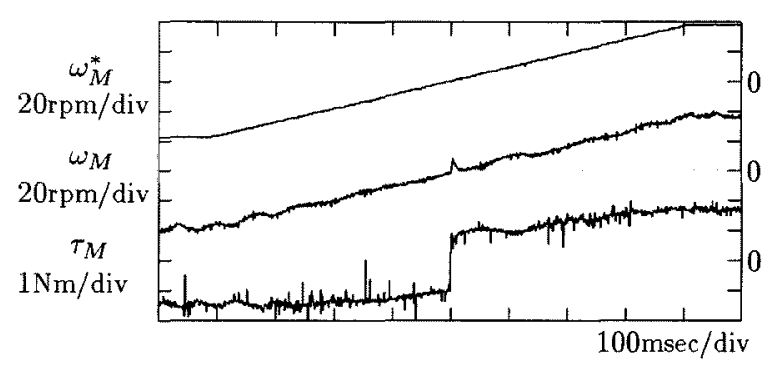

図 4 バンバン制御による速度反転特性

Fig. 4. Velocity profile using Bang-Bang control.

す値に設定し，電動機速度指令 $\omega_{M}^{*}$ は-40から+40 rpm へ $100 \mathrm{rpm} / \mathrm{s}$ の一定加速で与えている。速度反転時に, 電動機 発生トルク $\tau_{M}$ の応答遅れに起因する $130 \mathrm{~ms}$ 程度の零速度 期間が電動機速度 $\omega_{M}$ に存在し，その結果，速度制御精度低 下が生じているのがわかる。

以下では, 従来から提案されている摩擦補償法の代表例 である,バンバン制御法と外乱オブザーバ併用形制御法の 特性を示す。

（1）バンバン制御法 ${ }^{(5)}$ この方法は，予め計測された 摩擦トルク特性から得られる補償トルク(バンバントルク; $\left.T_{B B}\right)$ を, 速度反転時や始動時に速度 PI 補償器の出力へ強 制印加する方法であり，極めて簡単で有用なフィードフォ ワード補償法である。

図 4 は, 図 3 と同じ速度指令, 速度 PI 補償器を用いた場 合に, $T_{B B}=1.5 \mathrm{Nm}$ でバンバン制御を行った場合の速度反 転特性である。PI 補償のみの場合に比べて, 速度反転時の $\tau_{M}$ が応答遅れのないものとなった結果, 零速度期間がなく なっているが, $\omega_{M}$ にはバンバントルクの設定詥差に起因す るオーバーシュートが見られ，過補償になっている。本結果 は，あらる動作条件下に対する摩擦特性が正確に得られ ない場合には，最畄なバンバントルクの設計が困難である ことを示唆している。

(2) 外乱オブザーバ併用形制御法 ${ }^{(8)}$ この方法は, よく 知られている一定外乱モデルに基づく外乱オブザーバ(14) (以 下，一定外乱オブザーバと呼ぶ)によって瞬時摩摖トルクを 推定し，その值を速度 PI 補偵器の出力に加えるものである。 機珹系の運動方程式は次式で与えられる。

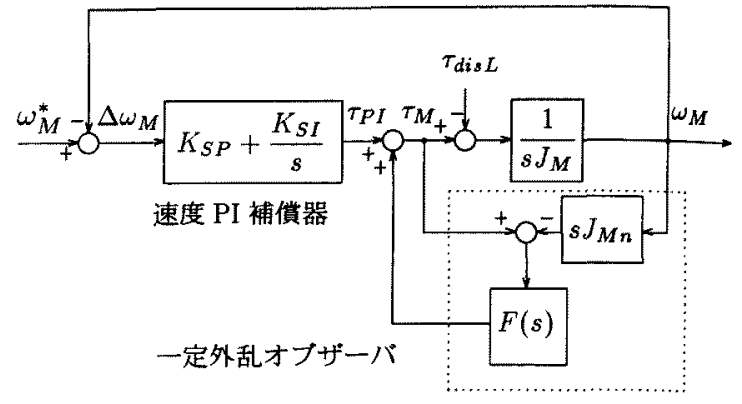

図 5 一定外乱オブザーバを用いた速度制御ブロック図 Fig. 5. Block diagram of velocity control with conventional disturbance observer.

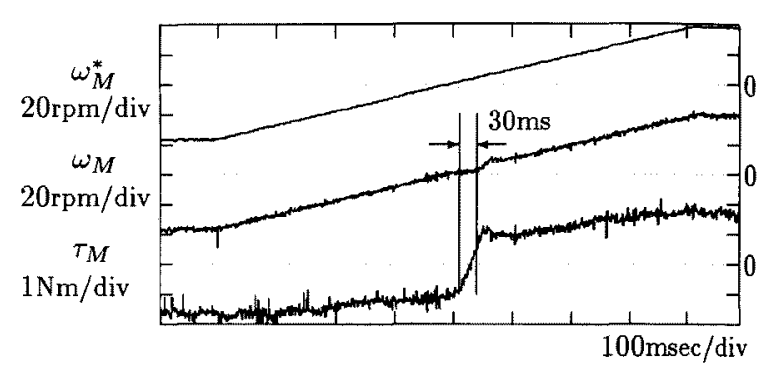

図 6 一定外乱オブザーバによる速度反転特性

Fig. 6. Velocity profile using conventional disturbance observer.

$$
\begin{aligned}
& J_{M} s \omega_{M}=\tau_{M}-\tau_{d i s L} \\
& \text { ここで, } \quad J_{M} ; \text { 電動機イナーシャ } \\
& \tau_{\text {disL }} ; \text { 摩擦トルクを含む外乱トルク } \\
& s ; \text { ラプラス演算子 }
\end{aligned}
$$

一定外乱オブザーバ $\widehat{\tau_{\text {dis } L}}$ は，外乱トルクの変化が系の機 械的時定数に比べて十分に遅いと言う仮定の下，(1) 式に $d \tau_{d i s L} / d t=0$ を加えて次式で最小次元オブザーバとして構 成される。

$$
\begin{aligned}
\widehat{\tau_{d i s L}} & =F(s)\left(\tau_{M}-J_{M n} s \omega_{M}\right) \\
& =\frac{1}{1+s \tau_{o b s}}\left(\tau_{M}-J_{M n} s \omega_{M}\right)
\end{aligned}
$$

$$
\begin{aligned}
& \text { ここで, } J_{M n} ; \text { 電動機イナーシャノミナル值 } \\
& F(s) ； \text { オブザーバフィルタ } \\
& \tau_{o b s} ; \text { オブザーバフィルタ時定数 }
\end{aligned}
$$

図 5 は, (2) 式の一定外乱オブザーバを速度 PI 制御系に付 加した場合の制御ブロック図であり，その場合の電動機発生 トルクは次式で与えられる。

$$
\tau_{M}=\left(K_{S P}+\frac{K_{S I}}{s}\right)\left(\omega_{M}^{*}-\omega_{M}\right)+\widehat{\tau_{\text {dis } L}}
$$

図 6 に, 図 3 と同じ速度指令, 速度PI 補償器を用い, $\tau_{o b s}=2$ $\mathrm{ms}$ と選んだ場合の速度反転特性を示す。速度反転時の電動 機発生トルク·速度それぞれの応答遅れはPI補償のみの場 合に比べて大幅に改善されているが, オブザーバの応答遅 れに起因する $30 \mathrm{~ms}$ 程度の雲速度期間が生じている。理諭 
的には $\tau_{o b s}=0$ と設定できれば摩擦の影響を完全に除去でき るが, オブザーバ入力に含まれる検出器高周波ノイズ等に よってその実現は不可能である。有限な応答周波数を持つ オブザーバを用いた場合，零速度期間ではオブザーバは適 切な摩擦トルクを推定できないため, 速度反転時には摩擦 補償機能が低下する。

3. クーロン摩擦特性を考慮した外乱オブザーバ によるフィードフォワード補供(11)(12)

前章の考察からわかるように, 従来から提案されている 摩擦補償法では十分な非線形摩擦補償の実現が困難である。 すなわち,バンバン制御による制御精度はフィードフォワー ド補償トルク $T_{B B}$ の大きさに強く依存し, 不完全な補償に 対する補正は考慮されない。また, $d \tau_{d i s L} / d t=0$ の仮定に基 づく一定外乱オブザーバ併用形制御の場合，速度方向反転 動作時の急激な摩擦変化に対する高速補償は望めず，その 結果, 速度・位置制御誤差が生ずる。本論文では,これらの 従来法の久点を克服すべく, クーロン摩擦モデルを考慮し た新しい外乱オブザーバを用いた非線形摩摖補償法を提案 する。

<3.1> クーロン摩擦特性を考慮した外乱オブザーバ

(1) 式に対して, 外乱トルクをクーロン摩擦としてモデリ ングした次式の運動方程式を基に，摩擦トルク $\tau_{f}$ に関する オブザーバを構成する。

$$
\begin{aligned}
&\left\{\begin{aligned}
& J_{M} s \omega_{M}=\tau_{M}-\tau_{f}, \tau_{f}=\operatorname{sgn}\left(\omega_{M}\right) T_{f c} \\
& \operatorname{sgn}\left(\omega_{M}\right)=\left\{\begin{aligned}
1 & \left(\omega_{M}>0\right) \\
-1 & \left(\omega_{M}<0\right)
\end{aligned}\right.
\end{aligned}\right. \\
& \text { ここで, } \quad T_{f c} ; \quad \text { クーロン摩擦トルクの大きさ } \\
& \operatorname{sgn}\left(\omega_{M}\right) ; \quad \omega_{M} \text { の符号関数 }
\end{aligned}
$$

(4) 式に対して, $d T_{f c} / d t=0$ の条件下でクーロン摩擦の大き さ $T_{f c}$ に対する最小次元オブザーバを構成すれば, 次式が得 られる。

$$
\left\{\begin{array}{l}
\widehat{T_{f c}}=\frac{1}{\operatorname{sgn}\left(\omega_{M}\right)} \frac{1}{1+s \frac{J_{M n}}{\operatorname{sgn}\left(\omega_{M}\right) L}}\left(\tau_{M}-J_{M n} s \omega_{M}\right) \\
\tau_{\text {obs }}=\frac{J_{M n}}{\operatorname{sgn}\left(\omega_{M}\right) L}
\end{array}\right.
$$

ここで，オブザーバゲイン $L$ は，設計パラメータである オブザーバフィル夕時定数 $\tau_{o b s}$ に対して設計されるため， $\operatorname{sgn}\left(\omega_{M}\right)$ によって符号が変化することに留意されたい。(5) 式の $\widehat{T_{f c}}$ を基に，次式のように符号関数を含んだ外乱オプ ザーバ $\widehat{\tau_{f}}$ を用いて，図７の様にフィードフォワード補償を 行う。

$$
\widehat{\tau_{f}}=\operatorname{sgn}\left(\omega_{M}\right) \widehat{T_{f c}}
$$

本補償法の場合, 電動機発生トルクは次式で与えられる。

$$
\tau_{M}=\left(K_{S P}+\frac{K_{S I}}{s}\right)\left(\omega_{M}^{*}-\omega_{M}\right)+\widehat{\tau_{f}}
$$

本提案オブザーバは, 電動機速度符号に応じてパラメー タの值が変化する一種の適応オブザーバであり ${ }^{(7)}$, 速度方

電学論D, 117 巻 4 号, 平成 9 年

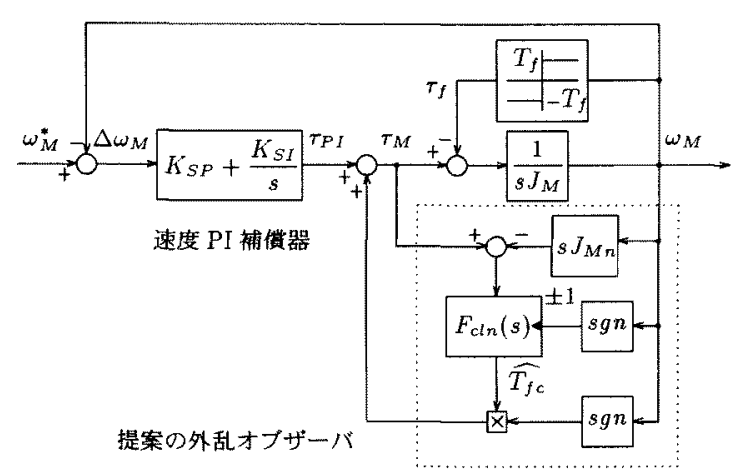

図 7 提案の外乱オブザーバを用いた速度制御ブロック図 Fig. 7. Block diagram of velocity control with proposed disturbance observer.

向が一定の場合には一定外乱オブザーバと同一の機能を示 し，速度方向反転時には $(6)$ 式の符号反転によりバンバン制 御之同様の応答遅れのない摩摖推定が可能であるという特 徵を有する。但し, バンバン制御と異なり，本オブザーバは 摩擦トルクに対する正確なモデルを必要としないことに留 意されたい。

$<3.2>$ 速度反転特性解析 図 6 からわかるように, 一定外乱オブザーバによる補償では，速度方向反転時には モータ発生トルクが静止摩擦トルクを越えるまでの間, 雺 速度期間 $\Delta T$ が発生して速度 、位置制御誤差を引き起こす。 ここでは,一定外乱才ブザーバ及び提案の外乱オブザーバ を用いたそれぞれの補償法の特性解析を，速度反転特性に 着目して考察する。

一定加速度 $\alpha$ の速度指令 $\omega_{M}^{*}$ による速度反転動作に対し て,一定外乱オブザーバ併用形の場合, 反転時の零速度期間 $\Delta T$ は, (2), (3) 式と (8) 式の各初期条件により (9) 式の 3 次 方程式の解で与えられる。

$$
\begin{aligned}
& \left\{\begin{array}{l}
\widehat{\tau_{d i s L}}(0)=\tau_{M}(0)=-T_{f}^{\prime} \\
\widehat{\tau_{\text {dis }}}(\Delta T)=\tau_{M}(\Delta T)=T_{f} \\
\omega_{M}^{*}(0)=\omega_{M}(0)=0
\end{array}\right. \\
& \begin{aligned}
\Delta T^{3}+\frac{3}{\omega_{n}}\left(\omega_{n} \tau_{o b s}+2\right) \Delta T^{2}+\frac{12 \tau_{o b s}}{\omega_{n}} \Delta T \\
\quad-\frac{6 \tau_{o b s}}{J_{M n} \alpha \omega_{n}^{2}}\left(T_{f}^{\prime}+T_{f}\right)=0
\end{aligned}
\end{aligned}
$$

ここで, $T_{f} ;$ 静止摩擦トルク

$T_{f}^{\prime} ;$ 動摩擦トルク $\left(T_{j}^{\prime} \leq T_{f}\right)$

$\omega_{n} ; \quad$ 速度 PI 補償器の固有角周波数

(9) 式の 3 次方程式は, $\tau_{o b s} \neq 0$ の下では摩擦特性の負勾配 の存在に依らず常に $\Delta T$ 正実根を持つことを示しており， その結果, 零速度期間が必ず存在することとなる。

一方, 提案の外乱オブザーバ併用形の場合も同様の動作 条件下で解析を行えば，(5)，(6)，(7) 式と(10) 式の各初期条 件により， $\Delta T$ は(11) 式の 3 次方程式の解で与えられる。 


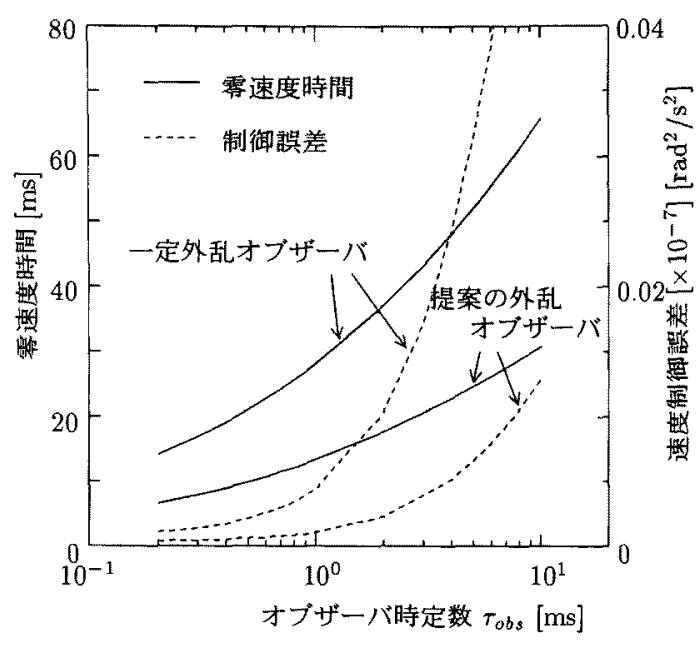

図 8 速度制御特性解析

Fig. 8. Analytical results of velocity control.

$$
\begin{aligned}
& \left\{\begin{array}{l}
\widehat{\tau_{f}}(0)=\widehat{T_{f c}}(0)=\tau_{M}(0)=T_{f}^{\prime} \\
\widehat{\tau_{f}}(\Delta T)=\tau_{M}(\Delta T)=T_{f} \\
\omega_{M}^{*}(0)=\omega_{M}(0)=0
\end{array}\right. \\
& \Delta T^{3}+\frac{3}{\omega_{n}}\left(\omega_{n} \tau_{o b s}+2\right) \Delta T^{2}+\frac{12 \tau_{o b s}}{\omega_{n}} \Delta T \\
& \quad-\frac{6 \tau_{o b s}}{J_{M n} \alpha \omega_{n}^{2}}\left(-T_{f}^{\prime}+T_{f}\right)=0
\end{aligned}
$$

(11) 式の場合は, $\tau_{a b s} \neq 0$ 又は $T_{f}^{\prime}<T_{f}$ の下では $\Delta T$ の正 の実根が存在することを示している。すなわち，摩擦特性 が $T_{f}^{\prime}=T_{f}$ のクーロン摩擦を示す場合には $\tau_{o b s} \neq 0$ であっ ても完全に摩擦の影響を除去可能であるが，一般に摩擦特 性が負勾配を持つ場合には $T_{f}^{\prime}<T_{f}$ となるため, 提案の外 乱オブザーバを用いても静止摩擦と動摩擦の差に応じて零 速度期間は発生する。しかし，(9) 式亡 (11) 式を比較すれ ば, (11) 式の定数項は (9) 式のそれよりも大きいため, 提案 の外乱オブザーバを用いた場合の零速度期間は一定外乱才 ブザーバを用いた場合に比べて常に短くなる。従って，提案 の外乱オブザーバによって，上り高精度な摩擦補償が期待さ れる。なお, 図 2 の摩擦特性には現れなかったが, $T_{f}^{\prime}>T_{f}$ なる状況となった場合には過補償を招く電動機発生トルク が印可され，応答速度には零速度期間は生じずにオーバー シュートが発生する。その場合には, 外乱才ブザーバが持つ 外乱抑圧機能により，オブザーバ時定数に依存する応答速 度によってオーバーシュートが補偵される(10)。

図 8 は, 図 6 と同条件の速度反転動作に於ける, オブザー バフィルタ時定数に対する零速度期間及び速度制御誤差の特 性解析結果である。特性解析では, 図 2(a)のシステム摩擦静 特性に倣って, 図 2(b) の摩擦モデルに $T_{f}=2.0 \mathrm{Nm}, T_{f}^{\prime}=1.5$ $\mathrm{Nm}, \omega_{M 0}=3 \mathrm{rpm}$ の各定数を用いて解析を行い, 速度制御 誤差は次式で表される速度偏差に対する 2 乗積分平均 $E$ で 評価している。

$$
E=\frac{1}{t_{2}-t_{1}} \int_{t_{1}}^{t_{2}}\left(\omega_{M}^{*}(t)-\omega_{M}(t)\right)^{2} d t
$$

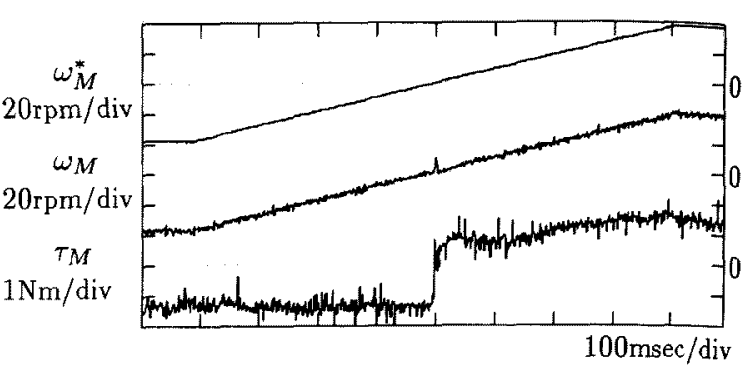

図 9 提案の外乱オブザーバによる速度反転特性

Fig. 9. Velocity profile using proposed disturbance observer.

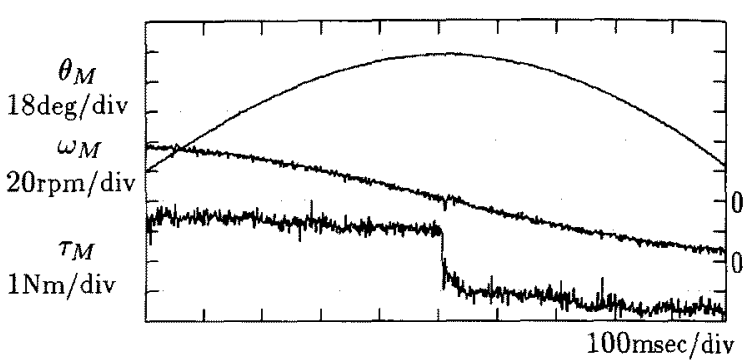

図 10 提案の外乱オブザーバによる軌跡制御特性

Fig. 10. Position control characteristics using proposed disturbance observer.

$$
\text { ここで, } \omega_{M}^{*}\left(t_{1}\right)=0, \omega_{M}^{*}\left(t_{2}\right)=40 \mathrm{rpm}
$$

図 8 から,例えば $\tau_{0 b s}=2 \mathrm{~ms}$ の場合, 提案の補償法では零 速度期間が一定外乱オブザーバのそれの約 $45 \%$ に減少でき， その絬果, 速度制御誤差は約 $20 \%$ に改善できている。

上記の解析は, 外乱トルクとして図 2(b) で示される摩擦 のみを考慮して行なったが，ロボットアーム等でよく経験さ れる一定方向の重力外乱トルク等が含まれる場合には，そ の影響は摩擦のモデリング誤差に起因する速度制御誤差と して現れる。そのような場合でも，反転動作後には外乱才 ブザーバと速度補償器による応答速度でその誤差は補償さ れるため, 従来の一定外乱オブザーバ併用形に比べて, 本提 案補償法は高精度なサーボ系が実現可能である。

\section{4. 実験結果}

$<4.1>$ 速度反転特性図 9 に，図 6 と同じ速度指令， 速度 PI 補償器, オブザーバフィル夕時定数を用いた場合の， 提案の外乱オブザーバ併用形補償による速度反転特性を示 す。図 8 の速度反転特性解析に依れば，図 2(a)の摩摖特性に 示される負勾配によって零速度期間が生ずるはずである。し かし，この場合の速度反転動作では，摩擦面の潤滑状態が変 化するほどの時間電動機は停止しないため, 図 2(a)の摩擦 静特性と異なり静止摩摖と動摩擦はほほ同等な値 $\left(T_{j} \simeq T_{f}^{j}\right)$ となっていると考えられる。そのため, 図 9 では速度応答 波形に零速度時間は存在していないが, 適切な摩摖補償卜 ルクの自動発生により, 図6の一定外乱オブザーバ併用形 補偵に比べて応答遅れのない良好な速度反転特性が得られ ている。 


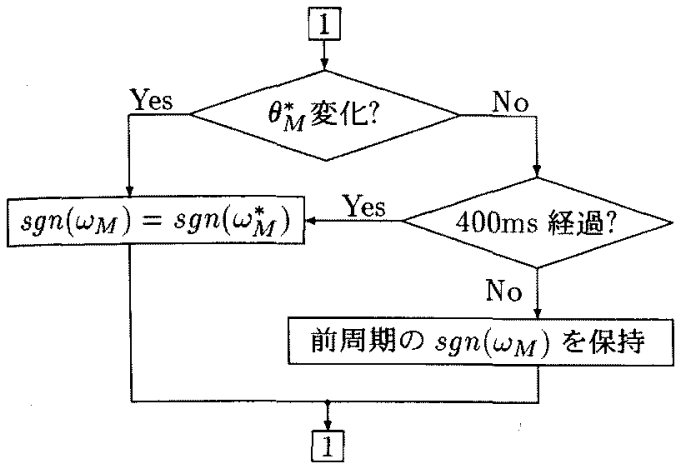

図 11 速度符号决定フローチャート

Fig. 11. Flowchart for determination of velocity sign.

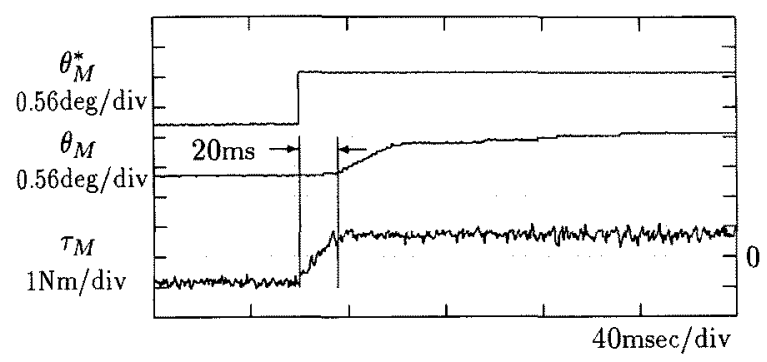

図 12 一定外乱オブザーバによる位置送り制御特性 Fig. 12. Positioning characteristics using conventional disturbance observer.

図 10 は, 図 7 で示される提案の速度制御系を, 位置制御 系の速度マイナーループとして適用した場合の軌跡制御特 性である。ここで, 軌跡指令としては振幅 $90^{\circ}$, 周波数 0.43 $\mathrm{Hz}$ の正弦波状位置指令を与元, 位置制御には比例補償 (P 補 償ゲイン $\left.K_{P P}=20 \mathrm{rad} / \mathrm{s}\right)$ を用い, 速度 PI 補償ゲイン, オ ブザーバ時定数は図 9 と同じである。提案の摩擦補償によ る応答遅れのない速度反転によって，精度の高い正弦波軌跡 が実現できていることがすかる。

$<4.2>$ 位置送り制御特性図 10 の軌跡制御に対し て, 位置指令が問欠的に变化する位置送り制御時には, 摩摖 の影響による電動機始動遅れによって位䈯制御誤差が生ず る。ここでは位置送り制御時の特性改善に関して検証する が, その場合, 提案の外乱オブザーバに用いる速度符号の決 定が重要となる。すなおち, 位置整定時には零速度で位置が 収束するため, 一般に速度符号にはチャタリングが生じ, 電 動機発生トルクにその影響が生ずる。そこで, 本補償法では 図 11 に示すフローに従って, 速度制御周期毎に速度符号を 決定するアルゴリズムを採用した。すなわち，電動機位置指 令 $\theta_{M}^{*}$ が变化した場合には電動機速度指令 $\omega_{M}^{*}$ の符号を (5) 式の $\operatorname{sgn}\left(\omega_{M}\right)$ に用い, $\theta_{M}^{*}$ が変化しない期間では位置制御 の応答周波数を考虑して $400 \mathrm{~ms}$ 間 $\operatorname{sgn}\left(\omega_{M}\right)$ を保持する。 ここで, 図 11 の速度符号決定フローは, 位置送り制御時の みならず上記の軌跡制御時等の場合にも有効である。

図 12,13 に, 図 10 の場合と同じ位置制御構成で $2 \mathrm{~s}$ 每に

電学論D, 117 巻 4 号, 平成 9 年

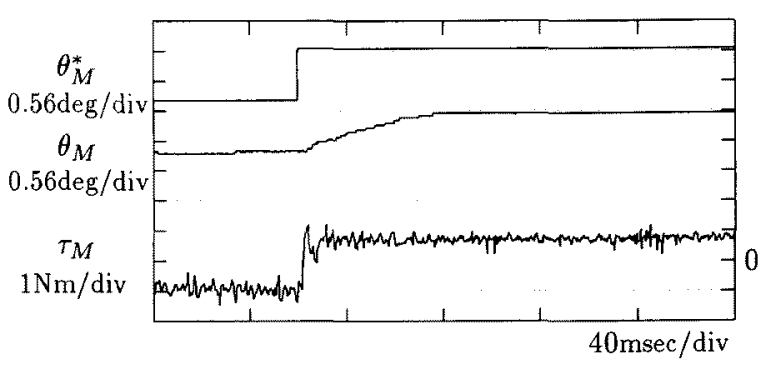

図 13 提案の外乱オブザーバによる位惪送り制御特性

Fig. 13. Positioning characteristics using proposed disturbance observer.

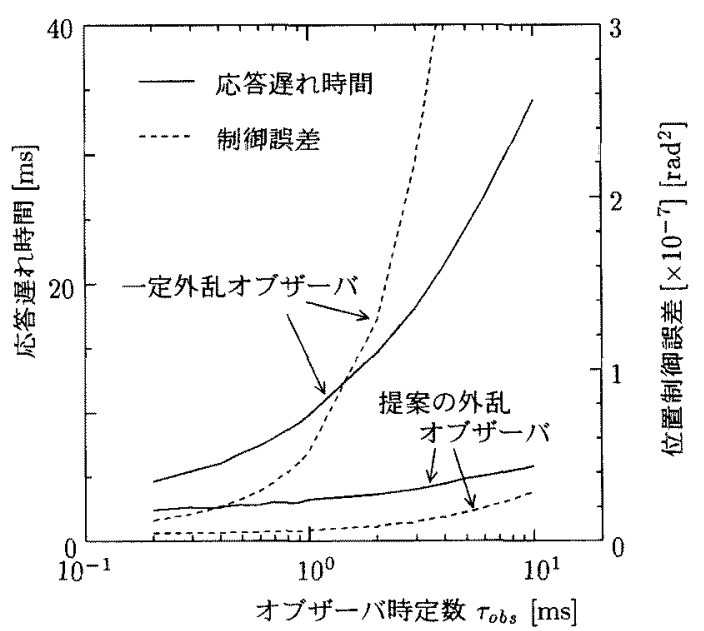

図 14 位置制御特性解析

Fig. 14. Analytical results of position control.

振幅 1゚のステップ状位置指令を与えた場合の, 各オブザー バに対する位置送り制御特性をそれぞれ示す。一般に, 位置 整定後の電動機発生トルクは $\pm T_{f}$ 間の值で摩擦と釣り合う が,ここでは共に負の摩擦トルクで整定している状態から の動作を示している。図 12 の一定外乱オブザーバの場合， 約 $20 \mathrm{~ms}$ の位置応答遅れ時間が生じ, その結果位置制御精 度が低下している。一方, 図 13 の提案の外乱才ブザーバの 場合, 位置指令变化後に速度指令による符号変化によって応 答遅れなく正の摩擦トルクが出力される結果, 良好な特性 が得られている。

図 14 は, 図 13 と同じ制御条件に対する,オブザーバフィ ル夕時定数に対する提案の外乱オブザーバ併用形補償法の 位置制御精度解析結果である。ここで, 摩擦モデルは図 80 場合と同じモデルを用い, 位置制御精度に関しては位置制御 誤差の 2 乗積分平均で評価している。この解析に於いても， 摩擦特性に負勾配を考慮しているため完全な摩擦補償は害 現できない結果になっているが，例えば $\tau_{o b s}=2 \mathrm{~ms} の$ 場合 には応答遅れ時間が約 $25 \%$ に, 位置制御誤差も的 $8 \%$ にそれ ぞれ大幅に低減されており，提案の補償法によって高精度な 位置決め制御が実現可能となることがわかる。 


\section{5. あとがき}

本論文では, クーロン摩擦を考虑した新しい外乱オブザー バによる電動サーボ系の非線形摩擦補償法を提案し，制御 特性解析, 供試システムによる実験によってその有効性を検 証した。本論文で得られた成果を要約すれば以下のように なる。

(1) 非線形摩擦の影響がサーボ系の制御精度に顕著に現れ る速度反転動作に対して, 従来から提案されている非線形 摩擦補償法による制御特性を実験的に検証し，その問題点 を明らかにした。

(2) 従来法の問題点を考慮して,クーロン摩擦モデルを用 いて構成される新しい外乱オブザーバを提案した。提案の 外乱オブザーバは電動機速度符号を内在する一種の適応才 ブザーバであり, 速度符号が一定の場合には従来の外乱才 ブザーバと同一の機能を有し，クーロン摩擦に対しては応 答遅れのない摩擦推定が可能である。

(3) 提案の外乱オブザーバを用いた補償制御系を構成した 結果, 正確な摩擦モデルを持つことなく, 従来の摩擦補償法 に比ベて高精度なサーボ系を実現した。提案の摩擦補償法 の有効性は, 供試システムに対する実験と特性解析によって 検証された。

本研究を進めるにあたり, 非線形摩擦現象について有益 な御助言を頂いた, 本学機械工学科松原十三生教授に感謝 の意を表する。

(平成 8 年 6 月 17 日受付, 平成 8 年 11 月 15 日再受付)

\section{文献}

(1) 鉿木, 三浦 : 「サーボ機構における Jerking Motionの計算」，電 学論, 87, pp.2261-2268 (昭 42-11)

（2）粟屋, 加藤，太田，三宅，伊藤：「クーロン摩摖が作用する機械運動 系のパラメータ同定法」，日本機械学会論文集，59,pp.3342-3348 (平 5-11)

(3) B. Armstrong-Hélouvry, P. Dupont and C. C. de Wit, "A Survey of Models, Analysis Tools and Compensation Methods for the Control of Machines with Friction", Automatica, 30, pp.1083-1138, (1994-7)

(4) C. C. de Wit, H. Olsson, K. J. Åström and P. Lischinsky, "A New Model for Control of Systems with Friction", IEEE Trans. of Automatic Control, 40, pp.419-425, (1995-3)

（5）是田, 沖友, 津村, 竹内, 江川：「バンバン制御による工作機械送 りの高精度化に関する研究」，精密工学会誌, $60, p p .427-431$ (平 6-3)

(6) 清水, 猪岡：「カルマンフィルタによる固体摩摖の推定 (第 3 報)」, 日本機械学会論文集 C, 55, pp.1506-1510 (平元-6)

（7）山田：「オブザーバによるサーボモータ系の固体摩摖の推定と位 置決め制御への応用」，計測自動制御学会論文集, 24, pp.162-169 (昭 63-2)

（8）遠藤，小林，吉田，小林，富堟，堀：「高速 X-Y テーブル用ロパス トトラッキングコントローラーの開発」, 日本機械学会ロボメッ ク’94 講演集, No.A211
(9) E. D. Tung, G. Anwar, M. Tomizuka : "Low Velocity Friction Compensation and Feedforward Solution Based on Repetitive Control", Trans. of the ASME, Journal of DSMC, 115, pp.279$284(1993-6)$

（10）岩崎, 鬼頭, 松井：「非線形摩摖を有する電動機速度制御系の特性 解析之摩擦補償」，電学論 C, 116, pp.96-102 (平 8-1)

（11）鬼頭, 岩崎, 松井：「クーロン摩擦オブザーバによる電動機位直制御 系の特性改善」, 電気学会半導体電力変換研究会資料, SPC-95-162 (1996-1)

(12) M. Iwasaki, N. Matsui : "Observer-Based Nonlinear Friction Compensation in Servo Drive System", Proc. of 4th International Workshop on Advanced Motion Control MIE, pp.344-348 (1996-3)

（13）吉田, 下郷，村野：「弾性構造系のディジタル最適制御」，日本 械学会論文集 C, 52, pp.3073-3081 (昭 61-12)

（14）例えば, 大西：「メカトロニクスにおける新しいサーボ技術」，電 学論 D, 107, pp.83-86 (昭 62-1)

岩 崎 誠 (正員) 昭和 39 年 1 月 15 日生。平成 3 年

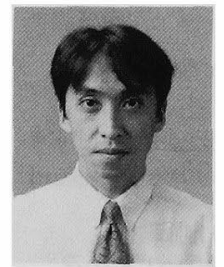
3 月名古屋工業大学大学院工学研究科博士 後期課程修了。同年 4 月名古屋工業大学助 手, 現在に至る。工学博士。モーションコン トロールの研究に従事。精密工学会, IEEE 会員。

鬼 頭 芳 明 (学生員) 昭和 48 年 2 月 23 日生。平成 7 年

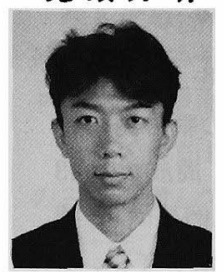

3 月名古屋工業大学電気情報工学科卒業。同 年 4 月名古屋工業大学大学院工学研究科博 士前期課程入学, 現在に至る。サーボ系の 摩擦補償の研究に従事。

松井信行 (正員) 昭和 18 年 5 月 7 日生。 43 年 3 月

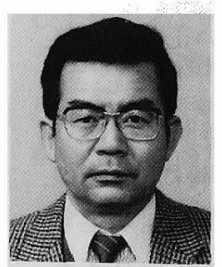
名古屋工業大学大学院修士課程修了。同年 4 月名古屋工業大学助手, 講師, 助教授を経 $\tau, 60$ 年 4 月同電気情報工学科教授, 現在 に至る。エ学博士。パワーエレクトロニク スおよびモーションコントロールの研究と 教育に従事。計測自動制御学会, 日本ロボッ 卜学会, IEEE 会貝。 